\title{
REMARKS ON THE POSSIBILITY \\ OF APPLYING THE MERCURY POROSIMETRY METHOD IN PETROPHYSICAL STUDIES OF ROCKS**
}

\section{INTRODUCTION}

Rock pore space is a rock mass composed of a large number of irregularly arranged and shaped pores. The diameter of the pores and their distribution and tortuosity determine the possibility of collecting and conducting reservoir fluids (Oil, Natural Gas and Saline water). The characterization of the pore space determines the distribution and size of the cavities in the rock. The characteristics of the study is based on parameters such as porosity and permeability, upon which the petrophysical static model is built.

The article presents the results of capillary pressure in graphical form for the Inoceramian sandstones of the Skole Unit, as part of the Outer Carpathians, made using the method of mercury porosimetry. On the basis of porosimetrics, the physical parameters of rocks are defined.

It has been known for centuries that oil is present in the Carpathians. Even Staszic in his work. About the history of the Carpathians and other mountains and Polish flatlands (1815) mentioned black oil seeping from the rocks. The local people quickly learned to use such natural benefits[6].

The natural oil spills and oil fields in the Skole Nappe discovered to date, as part of the Outer Carpathians, are in the eastern part of its internal synclinorium. The largest oil reserves previously documented in the fold Łodyna-mine (-Witryłów) in the Kliwasandstonesof Menilitelayers, are characterized by a good effective porosity and intergranular permeability. In the fold that achieved the industrial tide of oil from older and younger sandstone series, i.e. Inoceramian and hieroglyphic sandstones (younger Cretaceous - older Eocene) on the Witryłów-Hłomcza oil field [1].

* AGH University of Science and Technology, Faculty of Drilling, Oil and Gas, Krakow, Poland

** Work performed within the statutory research program of the Faculty of Drilling, Oil and Gas AGH UST No. 11.11.190.555 


\section{THE GEOLOGICAL OUTLINE AND LOCATION OF THE STUDY AREA}

The study area is located within the eastern part of the Skole unit near the Lodyna oil field. From the geological point of view, the Skole unit is a part of the Outer Carpathians Mountains which are built from many nappes, folds and scales usually over thrusting in a northerly direction $[1,12]$.

The Skole unit is built from formations from the lower Cretaceous to the Oligocene - early Miocene. The accumulation of oil in this area is related to the layers: the Inocereamian (upper Cretaceous - Paleocene), the Hieroglyphic (Eocene) and Ten Menilite (Oligocene) [5]. In the Skole unit, the largest deposits of oil are the Wańkowa and the Łodyna ones. The rock samples were collected from the Inoceramian sandstones near the Łodyna deposit (Fig. 1).

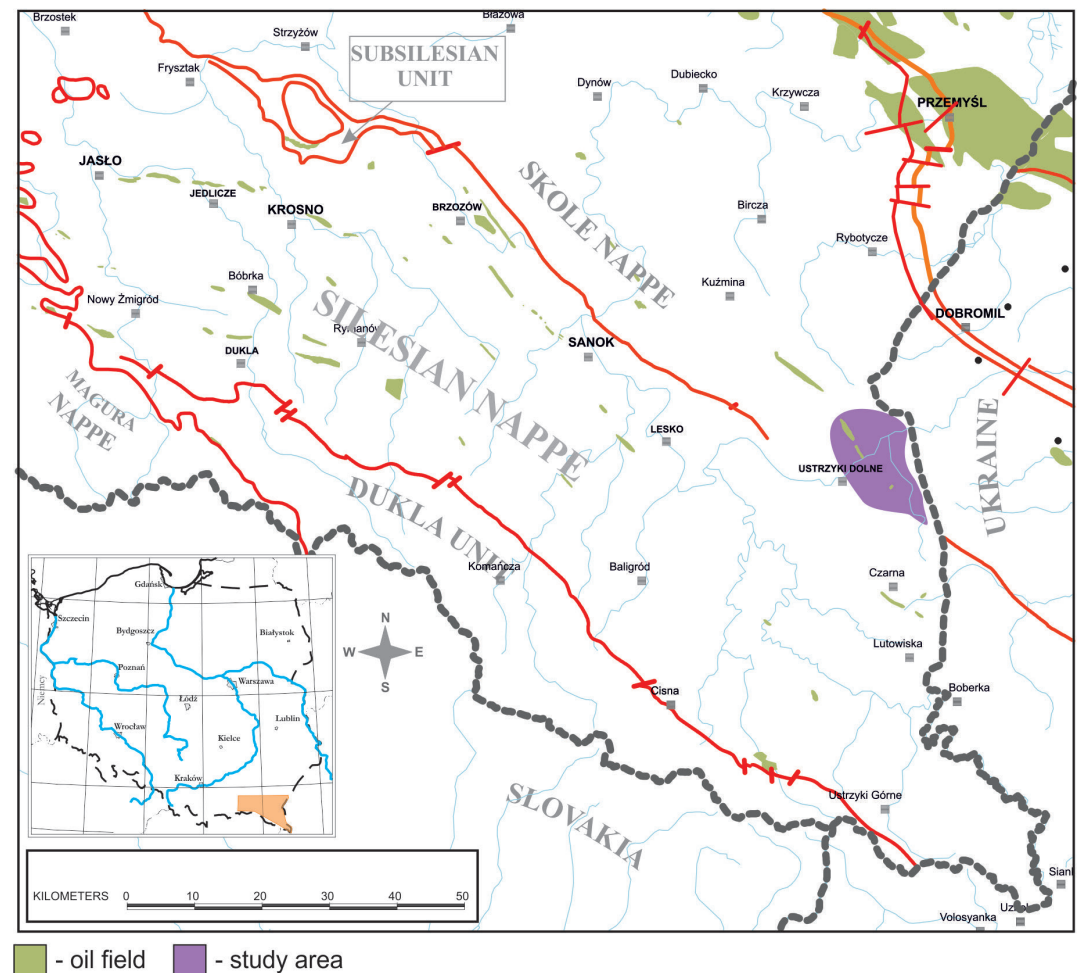

Fig. 1. Study area location on geological units

Source: [4; modified]

\section{CHARACTERISTICS OF THE MERCURY POROSIMETRY METHOD}

Washburn proposed his popular method for correlating entry pressure with pore radius in 1921 and mercury intrusion has been widely used by the petroleum and geoscience community for rock characterization and pore throat size distribution analysis (TSD); 
however its use is not limited to the evaluation ofporevolumesorTSDanalysisalone.Comparedtoothercharacterizationmethods, mercury porosimetry has proven to be a lot faster and more importantly, covers a wider range of pore sizes, from larger macropores to finer mesopores of up to 3.6 nanometers in diameter based on current available commercial porosimeters [8].

Porosimetric research is also called capillary pressure curve studies or research of pore radii distribution. For these studies, mercury porosimeters are used. The measurement is based on injecting mercury (nonwetting liquid) into the pore space in the studied rocks. Injection pressure (capillary) is associated with pore radii by Washbourne formula (1), using a cylindrical model of rock pore space [10]:

$$
P_{c}=\frac{2 \sigma \cos \theta}{r}
$$

where:

$$
\begin{aligned}
P_{c} & - \text { capillary pressure }[\mathrm{Pa}], \\
\sigma & - \text { surface tension }[\mathrm{N} / \mathrm{m}], \\
\theta & - \text { contact angle }\left[^{\circ}\right], \\
r & - \text { the radius of capillary tube }[\mathrm{m}] .
\end{aligned}
$$

Intrusion of mercury into the system of voids involves penetration of the throats. Once the mercury attains the pressure required to enter a throat, it proceeds to fill the pore connected to it. Only those throats connected to an empty pore at the time of their penetration are actually measured by mercury porosimetry. Extrusion is controlled by the size of the pores. During extrusion, some regions of the filled pores become isolated from the exterior and are nolonger accessible. This isolation results in mercury retention within the samples. Ideally, the fraction of retained mercury is characteristic of the type of porous network geometry being measured. Further, the number of pores measured at a given radius of the sample is less than the number of pores actually present in the network. This phenomenon primarily affects the largest pores because they tend to be the last to extrude and are most likely to be stranded. If no volume of mercury is extruded from them, they are not measured $[3,7]$.

The aim of porosimetry analysis is the physical characterizationof the pore space of reservoir rocks in the assessment of the quantitative parameters of rock densities, effective porosity, pore space geometry, the average pore diameter and the size of its surface area. From porosimetry analysis the following parameters can be obtained [9]:

- rock density $\left[\mathrm{g} \cdot \mathrm{cm}^{-3}\right]$, which is the quotient of sample mass and its volume in the dimension of skeletal and bulk density;

- effective porosity [\%], calculated from the ratio of the volume of the injected working fluid $\left[\mathrm{ml} \mathrm{Hg} \cdot \mathrm{g}^{-1}\right.$ of rock] and reservoir bulk density $\left[\mathrm{g} \cdot \mathrm{cm}^{-3} \cdot 100 \%\right]$;

- the average pore diameter $[\mu \mathrm{m}]$, calculated as a weighted average, the weight of the pores for the entire range of pore diameters present in the sample;

- surface area of the pore space $\left[\mathrm{m}^{2} \cdot \mathrm{g}^{-1}\right.$ of rock], being the sum of the surface pores present per unit mass of rock; surface area is a measure of the size of the flow fluid resistance in porous media. 
A result of porosimetric research are capillary pressure curves. Capillary pressure curves and their hysteresis depend on the geometry of the pore structure, the wetting properties of the individual pores of a porous sample, and also on the accessibility of the pores from the surface of the sample.

Reservoir rocks are classified in terms of their capillary-pressure curve form. This is because capillary-pressure curve form is controlled by various properties which can be measured and because curve form is strongly correlated with recovery efficiency [7].

Quantitative analysis of capillary pressure curves can also specify the ranges of the critical diameters of pores, whose contribution is decisive for the reservoir capacity of tested samples and differentiate their genetic type of relationship: intergranular pores - microcracks. On this basis, three genetic types of oil reservoirs can be distinguished:porous (I), porous-fractured (II), fractured (III)(the latter about the dominance of microcracks in the whole tank capacity) [9].

In material engineering and chemistry,classification in accordance with the standards adopted by the International Union of Pure andApplied Chemistry (IUPAC), is most commonly used and which, depending on the limits of pore diameters distinguishes [11]:

- macropores, $>50 \mathrm{~nm}$,

- mesopores(also called transient pores), 2-50 nm,

- micropores, $<2 \mathrm{~nm}$.

Also most commonly used in petroleum geology, rock physicsand hydrogeology, pore classification according to their size, due to the possibility of displacement water in them, distinguishes [11]:

- over-capillary (sometimes referred to as "normal") - sizes over $0.5 \mathrm{~mm}$,

- capillary - sizes from $0.5 \mathrm{~mm}$ to $0.2 \mu \mathrm{m}$,

- sub-capillary - size less than $0.2 \mu \mathrm{m}$.

According to Larson and Morrow, variations in the capillary-pressure curve shape reflect a variation in pore structure. They further explain that geometrically similar porous media will have capillary pressure curves which are identical in shape and can be correlated by a factor which is equal or proportional to some microscopic length [7].

\section{POROSIMETRY ANALYSIS OF SELECTED OF ROCK SAMPLES}

Measurements by mercury porosimetry allow for the identification of potential reservoir rocks, evaluation of their quality and the expected saturation of fluid resource properties. The essence of this method is based on the assumption that the capillary pressures are the result of the interaction of the forces acting inside the liquid, ie. The cohesive forces between liquid and saturating pore space and the structure of rock or adhesion [9].

To make the measurements and observations field measurements of varying spatial orientation within the sandstone outcrop packageswere selected and precisely localized.

Quantitative and qualitative research of the pore space of the analyzed samples wasmade by means of a mercury porosimeter AutoPore II 9520 from Micromeritics. Based on the measured values of pressure and intrusion of mercury, the measuring apparatus determines the vol- 
ume of pores and their distribution. The AutoPore IV 9520 analyzes up to a maximum pressure of $60,000 \mathrm{psi}$, giving the ability to measure pore diameters from $0.003 \mu \mathrm{m}$ to $500 \mu \mathrm{m}$.

The study of the properties of reservoir rocks covered porosimetric investigations in terms of parameters such as effective porosity, bulk and skeletaldensity, the average diameter of the pore, surface area and type of reservoir space. In this regard, porosimetric analyzes for 6 samples were performed (Tab.1).

Table 1

Summary of porosimetric test results for selected samples

\begin{tabular}{|c|c|c|c|c|c|c|c|c|c|}
\hline \multirow{2}{*}{ Sample } & $\begin{array}{c}\text { Bulk } \\
\text { density }\end{array}$ & $\begin{array}{c}\text { Skeletal } \\
\text { density }\end{array}$ & $\begin{array}{c}\text { Total } \\
\text { intrusion } \\
\text { mercury } \\
\text { volume }\end{array}$ & $\begin{array}{c}\text { Compact- } \\
\text { ness }\end{array}$ & $\begin{array}{c}\text { Effective } \\
\text { porosity }\end{array}$ & $\begin{array}{c}\text { Oil } \\
\text { effective } \\
\text { porosity }\end{array}$ & $\begin{array}{c}\text { Gas } \\
\text { effective } \\
\text { porosity }\end{array}$ & $\begin{array}{c}\text { Average } \\
\text { pore } \\
\text { diameter }\end{array}$ & $\begin{array}{c}\text { Total } \\
\text { pore } \\
\text { area }\end{array}$ \\
\cline { 2 - 11 }$[\mathrm{g} / \mathrm{cm}]$ & {$\left[\mathrm{g} / \mathrm{cm}^{3}\right]$} & {$[\mathrm{mL} / \mathrm{g}]$} & {$[\%]$} & {$[\%]$} & {$[\%]$} & {$[\%]$} & {$[\mu \mathrm{m}]$} & {$\left[\mathrm{m}^{2} / \mathrm{g}\right]$} \\
\hline $\mathrm{X} 1$ & 2.5695 & 2.6051 & 0.0053 & 98.633 & 1.3618 & 0.37 & 0.45 & 0.1159 & 0.920 \\
\hline $\mathrm{X} 2$ & 2.2275 & 2.2976 & 0.0137 & 96.949 & 3.0517 & 0.6 & 0.79 & 0.0457 & 1.198 \\
\hline $\mathrm{X} 3$ & 2.4118 & 2.6179 & 0.0326 & 92.127 & 7.8625 & 1.1 & 2.8 & 0.1509 & 0.865 \\
\hline $\mathrm{X} 4$ & 2.4607 & 2.7021 & 0.0363 & 91.066 & 8.9323 & 1.1 & 3.18 & 0.1578 & 0.184 \\
\hline $\mathrm{X} 5$ & 3.9401 & 4.2194 & 0.0168 & 93.381 & 6.6193 & 0.53 & 1.35 & 0.1523 & 0.441 \\
\hline $\mathrm{X} 6$ & 2.4832 & 2.5255 & 0.0067 & 98.325 & 1.6637 & 0.349 & 0.46 & 0.0418 & 0.645 \\
\hline
\end{tabular}

A graphic presentation of the results of research are graphs showing the increase in the size of porosity up to its maximum value as a function of pore size (Fig. 2). Effective porosity for the test samples is in the range of $1.3 \%$ to $8.9 \%$. The smallest porosity values are observed for samples X1, X2, X6, which is confirmed on the graph of the pore space geometry (Fig. 3).

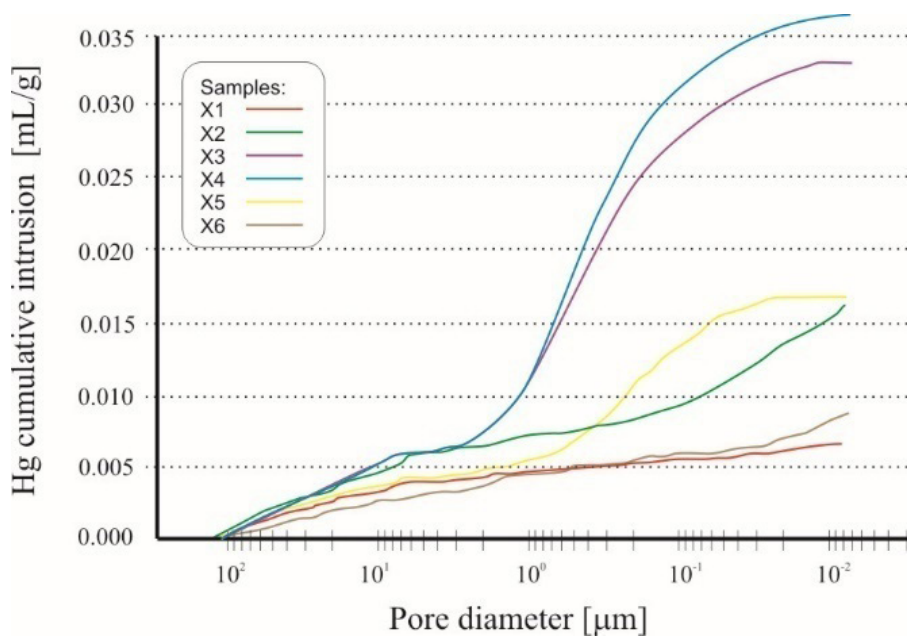

Fig. 2. Cumulative intrusion vs. pore size diameter for research samples 
An example of a distribution graph of pore space geometry for the study samples is shown below.

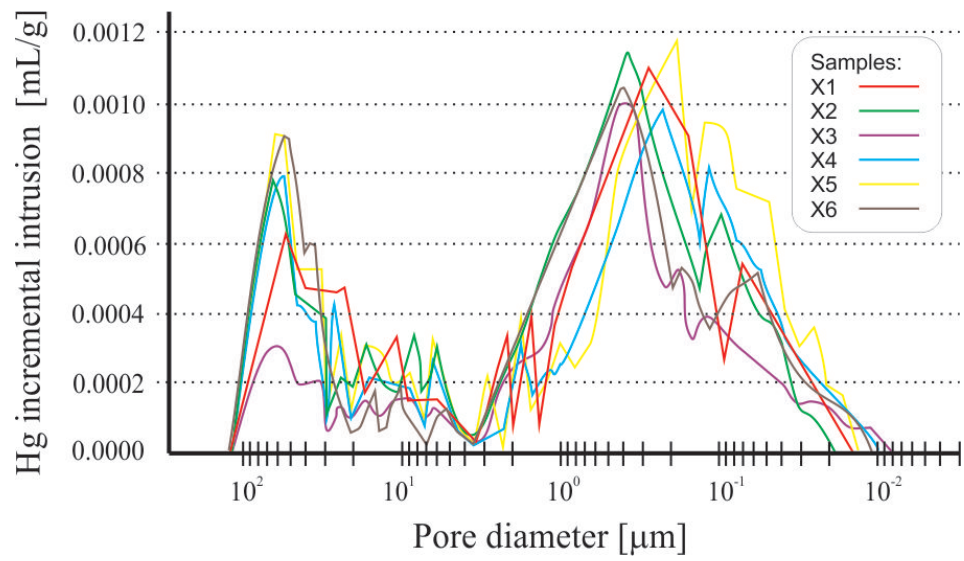

Fig. 3. Incremental intrusion vs. pore size diameter for research samples

The authors demonstrated the applicability of the mercury porosimetry method in the petrophysical study of the rocks by comparingthecharacteristics of the pore space for two samples: close to conventional rock (X4) and unconventional (X1). The measured skeletal density of the sample X1 is $2.61 \mathrm{~g} / \mathrm{cm}^{3}$, a bulk density $-2.57 \mathrm{~g} / \mathrm{cm}^{3}$. The effective porosity of $1.36 \%$, effective for gas $0.45 \%$ and $0.37 \%$ for crude oil, determines the size of the mean capillary 0.12 microns, specific surface area $S=0.920 \mathrm{~m}^{2} / \mathrm{g}$ and the threshold diameter of sample is $7.01 \mathrm{~mm}$. The compactness of the sample is $98.63 \%$ (Tab. 1).

In the example diagrams (Fig. 4) we can observe the image characteristic of the rocks of the pore space of two kinds, composed of cracks and micropores. The graph distribution of pore geometry is reflected in two systems of slots - the first, with an opening approx. $89 \mu \mathrm{m}$ to $62 \mathrm{~mm}$, with a maximum diameter $71.13 \mathrm{~mm}$, the second, with a maximum diameter $23.5 \mathrm{~mm}$. Another broad peak distribution shown in the graph of maximum pore geometry of the expansion volume of mercury press-fit, per diameter $8.56 \mathrm{~mm}$ pore system is an image with diameters between $1.9 \mu \mathrm{m}$ and $10.5 \mathrm{~mm}$. For the sample X1, in a range of diameters from 0.01 to several microns, animage characteristic of the pore-fracture spaceis observed.

The sample X4 has parameters close to conventional rock. The effective porosity of this sample is $8.93 \%$, effective porosity for gas $3.18 \%$ and $1.1 \%$ for crude oil determines the size of the mean capillary 0.16 microns, specific surface area $S=0.184 \mathrm{~m}^{2} / \mathrm{g}$ and the threshold diameter of sample is $8.11 \mu \mathrm{m}$. The compactness of the sample is $91.06 \%$ (Tab. 1). In the example diagrams (Fig. 5) we can observe the image characteristics of the rocks of the pore space of two kinds, namely those composed of cracks and micropores. The graph distribution of pore geometry are reflected in two systems of slots - the first, with an opening approx. $89 \mathrm{~mm}$ to $62 \mathrm{~mm}$, with a maximum diameter $71.13 \mathrm{~mm}$, the second, with a maximum diameter $23.5 \mathrm{~mm}$.

Analysis of the results of the porosimetric lithotypes study series shows that the Inoceramian sandstones on the site represent rocks with a very low porosity, type of pore-fracture space and low volume of pore space for oil and natural gas. 

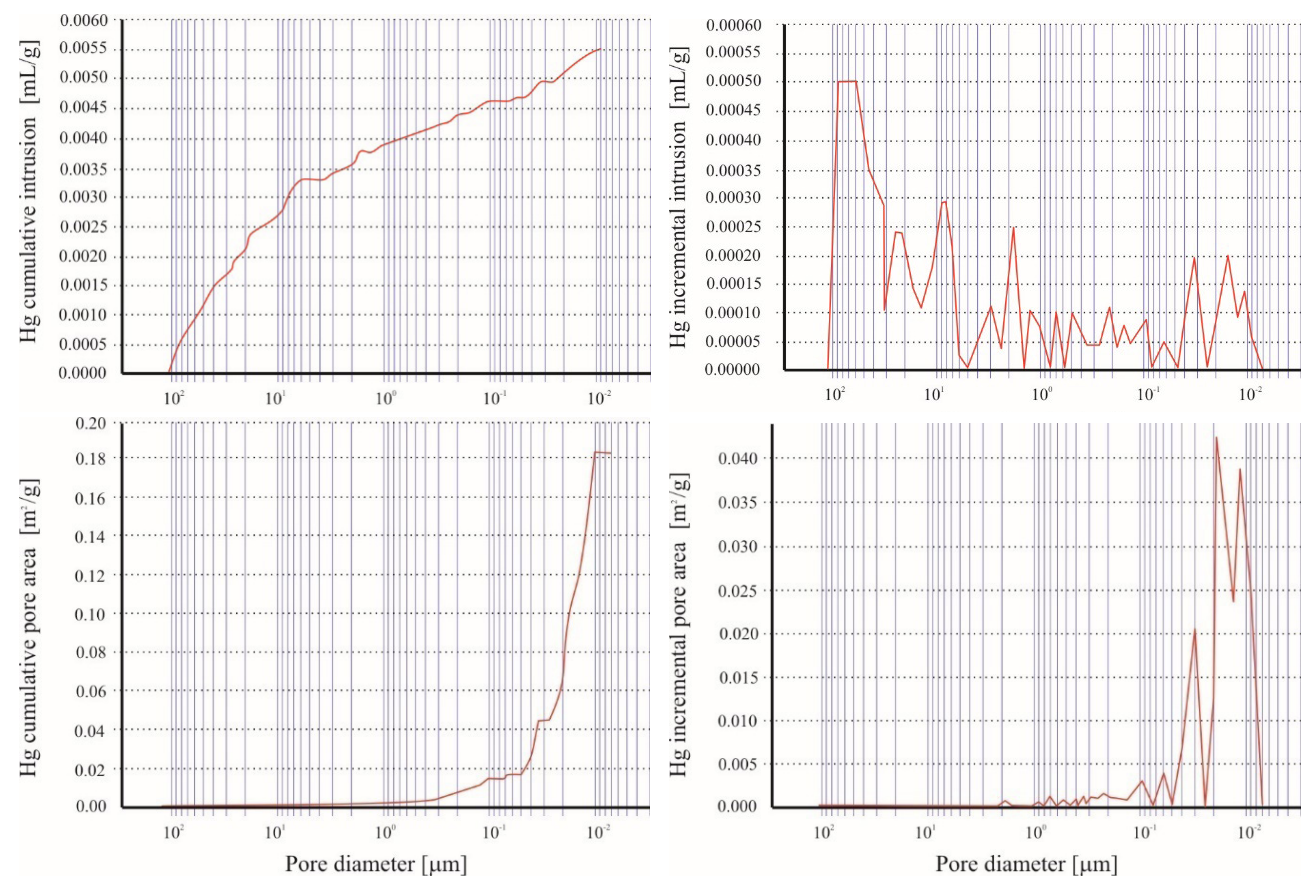

Fig. 4. Mercury intrusion porosimetry curves for sample X1
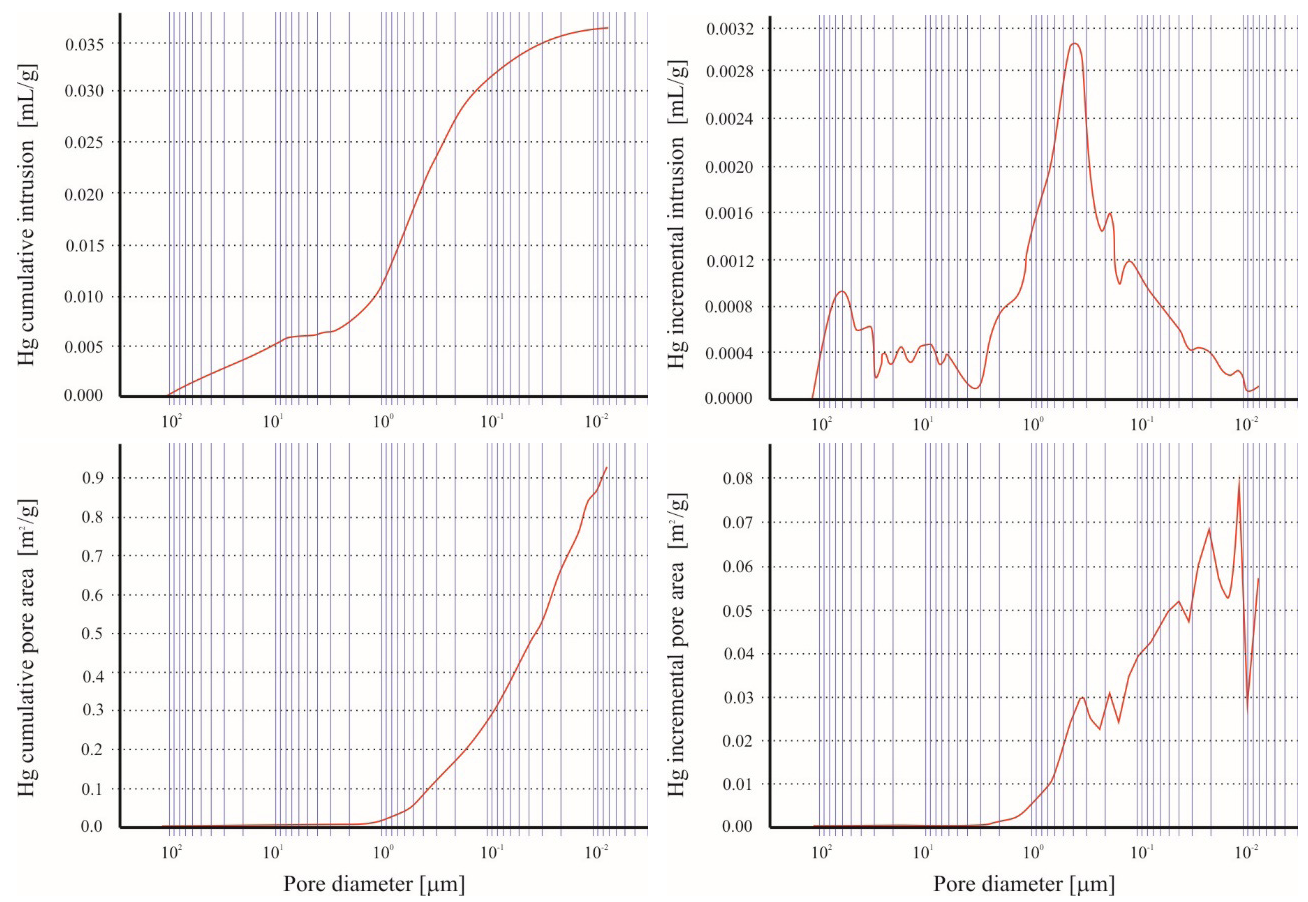

Fig. 5. Mercury intrusion porosimetry curves for sample $X 4$ 


\section{CONCLUSIONS}

The research of the pore space is one of the most important research relies on the mathematical description of transport and storage of reservoir fluids. Fluid behavior in porous media is determined by the arrangement of pore bodies and throats in the porous medium, fluid properties, and rock/fluid interactions.

The study used the method of mercury porosimetry, which consists of injections of a non-wettability fluid (mercury) into the porous medium.In order toevaluate the petrophysical parameters of sandstone, the available porosimetric dataset was used and on whose basis an attempt to assess the rocks studied. Analysis porosimetry had to answer the question about the existence of sandstone rock that could create a reservoir for unconventional hydrocarbon deposits (of the tight type).

The Inoceramian Sandstone ofthe Skole unit area are characterized by a pore-fracturetype reservoir space of a monomodal. The analysis indicated that the type of rock presentedhas poor reservoir characteristics, low capacitance gas and low capacity for oil in the studied area.

The presented results were considered preliminary due to the limited data. The mercury porosimetry method is useful for investigating conventional reservoirs because of the limited range of pore diameters. In the case of the author's research, the samples had the features of reservoir and sealing rocks. In the next step, an attempt will be made to measure the petrophysical parameters by means of helium porosimetry. The method will use helium due to its chemically neutral nature and small molecular dimensions.

\section{REFERENCES}

[1] Karnkowski P.: Złoża gazu ziemnego i ropy naftowej w Polsce. Karpaty i Zapadlisko przedkarpackie. T2, „Geos”, AGH, Kraków 1993.

[2] Kotlarczyk J.: Stratygrafia formacji z Ropianki ( $\mathrm{fm}$ ), czyli warstw inoceramowych w jednostce skolskiej Karpat fliszowych. Prace Geologiczne PAN, nr 108, Warszawa 1978.

[3] Lane A., Shah N., Conner W.C.: Measurement of the Morphology of High SurfaceArea Solids: Porosimetry as a Percolation Process. Journal of Colloid and Interface Science, vol. 109, no. 1, 1986, pp. 235-242.

[4] Maćkowski T., Kuśmierek J., Reicher B., Baran U., Kosakowski P., Łapinkiewicz A.P., Machowski G., Papiernik B., Szczygieł M.: Dwuwymiarowe modele termicznego przeobrażenia materii organiczneji ekspulsji węglowodorów w transgranicznej strefie Karpat polsko-ukraińskich. Geologia, t. 35, nr 4/1, 2009, pp. 191-222.

[5] Marcinkowski A., Szewczyk E.: Produktywność karpackich skat zbiornikowych w'świetle historii wydobycia węglowodorów, Geologia, t. 34, nr 3, 2008, pp. 405-421.

[6] Maruta M., Sala D.: Oil seeps and natural environment in the Polish Carpathians preliminary results, in: Interdisciplinary topics in mining and geology T4, red. J. Drzymała, W. Ciężkowski. Oficyna Wydawnicza Politechniki Wrocławskiej, Wrocław 2013, pp. 119-127. 
[7] Owolabi O.O., Watson R.W.: Estimating Recovery Efficiency and Permeability From Mercury Capillary Pressure Measurements for Sandstones. Eastern Regional Conference \& Exhibition, Pittsburgh, USA, 1993.

[8] Salimifard B., Ruth D.W., Nassichuk B.: A Study of Mercury Intrusion on Montney Formation Rocks and How It Relates to Permeability. SPE Unconventional Resources Conference, Calgary, Alberta, Canada, 2015.

[9] Semyrka R., Semyrka G., Zych I.: Zmienność parametrów petrofizycznych subfacji dolomitu głównego zachodniej strefy półwyspu Grotowa w świetle badań porozymetrycznych. Geologia, t. 34, z. 3, 2008, pp. 445-468.

[10] Such P.: Nowoczesne metody badania właściwości petrofizycznych skat oraz możliwości zastosowania otrzymanych wyników w badaniach diagenezy. Przegląd Geologiczny, t. 45, nr 8, 1997, pp. 781-784.

[11] Twardowski K., Traple J.: Charakterystyka ilościowa porowatości ośrodków gruntowo-skalnych a zjawiska molekularno-powierzchniowe. Wiertnictwo, Nafta, Gaz, t. 23, nr 1, 2006, pp. 487-495.

[12] Warszyńska J.: Karpaty polskie. Wydawnictwo Uniwersytetu Jagiellońskiego, Kraków 1995. 